JAKUB STELINA ${ }^{1}$

\title{
New rules for employing university teachers in the Statute on Higher Education and Science
}

\begin{abstract}
In the article, the author discusses the basic assumptions of the reform of the Law on Higher Education and Science, which is to be introduced in Poland in autumn 2018 , with particular emphasis on the rules of employing university teachers. One of the most important changes in this area is the resignation from appointment as a basis for establishing employment relationships with this professional group in favour of an employment contract. It is the end of the process of departing from the employment model based on the special status of university teachers, which has lasted for over a dozen years. Now, they will largely be subject to general labour law regulations. This means making the legal regulation more flexible and therefore also reducing the protection against dismissal, the right to which has been vested in the appointed teachers so far. The author also believes that the changes currently being implemented are only the first stage of the reform, which should result in a significant increase in financial outlays for higher education institutions and in the approximation of the level of salaries of university teachers to standards in developed countries.
\end{abstract}

Keywords: university teachers, labour law in higher education, appointment, employment contract, salaries of university teachers

Prof. Jakub Stelina - Dean of the Faculty of Law and Administration, University of Gdansk, Chief of the Department of Labour Law; e-mail: jstelina@prawo.ug.edu.pl; ORCID: 0000-0003-2871-1413. 
$\mathrm{T}$ he new Act - Law on Higher Education and Science - called the "Constitution for Science" or "Law 2.0", entering into force in autumn 2018, has been yet another reform of this area of social life for the last dozen or so years. It is to supersede the Act of 27 July 2005 - Law on higher education ${ }^{2}$ - and a slightly earlier Act of 14 March 2003 on academic degrees and academic title as well as on degrees and title in arts. ${ }^{3}$ It should be also pointed out here that pursuant to the amendment of the both laws, new far-reaching solutions have been implemented both in the organisation of higher education and in the scientific advancements in 2011 and 2014. Therefore, we had to do with the legislator's fourth approach to the issue in question since 2005 (excluding, of course, a number of minor amendments). Therefore, if we measure the condition of a specific fragment of social reality using the number of changes made to the legal regulations relating to it, the area of higher education and science quite unexpectedly appears to be exceptionally unstable in "normative" terms. However, it would be a mistake to think that such a state is unique because it is the periods of relative stability that have been rare in the last hundred years. The Law on Higher Education and Science has already been the eleventh comprehensive regulation covering these issues, which means that - excluding numerous amendments - new legal acts in this field were adopted more often than once every ten years. ${ }^{4}$ Some of them were obviously dictated by strictly political factors, the system of the state has changed twice since 1918, and thus have the perception of the role and tasks of the system of higher education. The role of universities, state-forming and serving the society, was strongly highlighted in the interwar period, ${ }^{5}$ whereas

I.e. Journal of Laws of 2017, item 2183.

I.e. Journal of Laws of 2017, item 1789.

4 Previous regulations were adopted in 1920, 1933, 1947, 1951, 1958, 1982, 1990 and 2005, but the regulations on the professional status of university teachers in 1928 and 1972 were in separate legal acts.

5 As can be read in the preamble of the Act of 13 July 1920 on Academic Schools, "Their task [i.e. of higher education institutions] is to serve science and the fatherland. To this end, they try to find truth in all branches of human knowledge and to serve as a guide on the path of learning this truth by academic youth and to spread it among the entire Polish nation in the name of principles underpinning the moral and mental improvement of the human race. (...) academic schools are to fulfil as faithfully as possible the noble task defined centuries ago for the oldest university by its founder, King Casimir the Great, wishing it to be a pearl of sciences, to educate prudent, mature and virtuous people expert in science and at the same time to be the fountain of skilful knowledge that everyone can draw from". 
the goal of the implemented changes in the period of real socialism was to replace the existing elites and - through the "social advancement" - to provide the new regime with human resources to guard the new order. On the other hand, the Acts of September 1990, ${ }^{6}$ adopted after the commencement of political changes in the late 1980s, restored greater autonomy to higher education, strengthened the freedom of research and freedom of teaching, based the system of higher education on the community idea and enabled the dynamic development of private schools, nonetheless, in terms of basic organisational assumptions, they were largely based on previous solutions. This also applied to staffing issues.

The model of higher education and science formed this way has continued in its basic framework to date. Actually, it was also preserved after the reforms of 2003 and 2005, when the new laws on these issues came into force, and seriously changed in 2011 as a result of the amendment implemented by the Act of 18 March 2011 amending the Law on higher education, the Law on academic degrees and academic title as well as on degrees and title in arts and about certain other acts, ${ }^{7}$ which, however, was partly withdrawn in 2014..$^{8}$ The Constitution for Science departs from this model and fundamentally changes the philosophy of functioning of universities in Poland. The justification for the prepared reform pointed out that the current system generates problems that "negatively affect the quality of scientific research conducted by Polish universities and scientific institutions as well as the level of education of students and doctoral students. The current rules of financing and evaluating scientific activities and development of scientific career are not aimed at achieving scientific excellence and hence contribute to the deepening of development pitfalls. This is a prerequisite for the reform of higher education and science, which covers changes in the functioning of the system, management, financing and quality assessment of universities - in the formula of a strategic project within the framework of the Strategy for Responsible Development. Better functioning of higher education and science is a condition for improving the quality of human and social capital". According to the author of the bill, the key systemic problems of higher education and science, in addition to insufficient funding, include, among other things, flawed rules for the organisation and system of universities that limit the opportunities for efficient management, mismatch of the structure of the higher

6 The Act of 12 September 1990 on Higher Education (Journal of Laws No. 65, item 385) and the Act of the same date on academic title and academic degrees (Journal of Laws No. 65, item 386).

7 Journal of Laws of 84 , item 455.

8 See the Act of 11 July 2014 amending the Law on higher education and certain other acts (Journal of Laws of 2014, item 1198). 
education system to social and economic challenges, limited financial autonomy of universities, unsatisfactory higher education quality, low effectiveness of doctoral education, defective system of scientific advancements that inhibits researchers' scientific excellence and conduct of interdisciplinary research, poor recognition of results of Polish scientific research in the global science.

Of course, not everything in the sphere of higher education and science functions improperly. It seems that the extremely negative assessment of academic didactics is not fully justified. It is hard to deny that the mass education of students did not result in the quality of granted diplomas, but this does not apply to all schools or all graduates. In a sense, we have developed - still imperfect, but nevertheless - a market of academic services with a distinct hierarchy of prestige. Candidates for studies know which universities are good and which are used only to obtain a diploma. A similar situation exists in many other countries, where the education level of some of the universities is close to the Polish upper- or even lower-secondary schools. In any case, massification does not affect solely universities. On the one hand, it was a response to evident social demand, namely a period of collapse after the times of the Polish People's Republic, when higher education was a scarce good. What should also addressed are the state school financing rules, which favoured the number of students (financing was granted for a student, so it was worth taking as many candidates as possible). Thanks to the opportunity for collecting tuition fees, education also at state-owned universities was often similar to running a business, which had an adverse impact on the quality of education, but it was also a way to raise funds not only for salaries, but also for scientific research.

However, it is no less the case that higher education generally ranks poorly, which is mainly due to the fact that it insufficiently satisfies the higher and higher civilisational aspirations of Poles. On the one hand, we did not have any Nobel Prize winners, there are very few scientists affiliated with Polish universities in prestigious international research projects, but on the other hand, the higher education is still not focused on co-operation with the social environment, in particular business. It generates a kind of "inferiority complex", whose most glaring manifestation is the fetish of world rankings in which Polish universities occupy distant places. The reason for this state of affairs indicated by academic circles for years is too low level of financial outlays for science, which translates not only into the lack of significant achievements, but also into disproportionately low salaries of Polish scientists compared to their colleagues from abroad. This means that young and talented graduates choose a different development path, take up a job in business or seek employment in foreign institutions. In response to these accusations, one can most often hear that increasing the funds will be of no avail if it is not accompanied by a profound structural reform of Polish science because the model of higher educa- 
tion and science inherited from the times of the Polish People's Republic is not able to meet the requirements of modern state.

In this state of affairs, there is a proposal for a very deep reform of both higher education and science, called - as mentioned earlier - "Constitution for science" or "Law 2.0". First of all, it decentralises the system by delegating a number of powers to higher education institutions (senates and rectors) to shape their system (e.g. internal organisation), thereby significantly broadening the scope of statutory matter. The statute of a university will specify the types of university organisational units (e.g. faculties, institutes, departments, divisions, colleges or centres). The existence of particular types of units will depend on the statute adopted by the senate, whereas the organisational structure will be determined by the rector. As you can see, the organisational autonomy of universities will be extended - the Act will no longer enforce a specific structure, but it will be at the discretion of the community of a given university. The senate will also adopt the university's strategy.

The position of rectors as university governing bodies will be strengthened, although to a certain extent their authority will be subject to councils (consisting partly of external persons) and to senates. The entities specified in the university statute and the university council will be able to suggest candidates for the rector. The rector's election will be conducted by the college of electors, which is a democratically elected representation of all members of the academic community of a given university. The college of electors does not include representatives from outside. The choice of the rector will be at the exclusive discretion of the academic community.

A change in the rules for the functioning of the entire higher education system will be of major importance. The legal and financial status of individual units will depend on the scientific results they achieve, i.e. not on their potential, but on how it is used. The rights vested in universities and its level of financing by the state will be determined not by formal grounds (e.g. the number of professors), but by substantive factors, i.e. the parametrically assessed quality of research and scientific publications. The system of parameterisation of units as well as the evaluation of academic staff will also change. Scientists will submit only four of their most important scientific achievements once every four years, thus the quality instead of the number of publications will be rewarded. The rights to award degrees will depend on the scientific category of the given unit from 2021.

There are also a number of solutions aimed at improving the quality of education of students (e.g. introducing a new academic career path that distinguishes excellent educators, longer and better internships for students in practical or interdisciplinary majors) and doctoral students (e.g. the introduction of doctoral schools and general scholarships at a fair level). 
We should also mention the solutions in the field of "academic" labour law. The Constitution for Science contains a number of very important changes in the legal status of academic staff. What should be addressed here is, above all, an increase in the regulatory importance of general labour law regulations, which - as is the case de lege lata - will be used as help to hire employees in higher education, but for a larger number of issues. The scope of matters related to employment relations has also been expanded, and it will be possible now to regulate them in the university's statute, which means that the legal regulations will be more flexible and hence it will be possible to adapt the employment model in a given university to its specifics and local conditions.

The changes in the status of university teachers include first of all the resignation from appointment as the basis for establishing an employment relationship in favour of an employment contract. On the one hand, it is the culmination of a certain process of departing from appointment. Until 2005, at first it was the only and later the main basis for employment of university teachers. The appointment itself (nomination) was related to the special, public-law status of all persons employed in public institutions. In the period of the Second Polish Republic and in the first decades of the Polish People's Republic, the people included in the "teachers' group" (i.e. professors, docents (senior lecturers) and auxiliary academic employees) were employed on the basis of nominations by a competent authority (minister or university body), and their legal employment relationships were official relations of a public nature. Although they were not included in the civil service corps, ${ }^{9}$ as state officials, they were not subject to private labour law. For example, pursuant to the Ordinance of the President of the Republic of Poland of 24 February 1928 on the official relations of professors of state academic schools and auxiliary academic employees of such schools, professors were appointed by the President of the Republic of Poland (at the request of the Minister of Religion and Public Education, submitted in accordance with the regulations on the organisation of academic schools), and the service relationship of a full and assistant professor became binding when the nomination letter was delivered to them. "Auxiliary academic employees", which included adjunct (assistant) professors, curators, constructors (instructors), prosectors, observers, senior assistants, junior assistants (demonstrators, military schools students) and deputy assistants, were appointed and dismissed by the senate at the request of the faculty council. Only deputy professors and persons with contracted lectures and exercises were employed on the basis of employment contracts. Similar regulations were also included in later post-war official pragmatics governing the

9 Pursuant to Article 118 of the Act of 17 February 1922 on state civil service, its provisions did not apply, among others, to the teachers of all state-owned schools. 
rights and duties of university teachers. ${ }^{10}$ Admittedly, the regulations in 1951-1972 provided for appointment as the basis for employment of university teachers, but in the light of law it was in fact a nomination. ${ }^{11}$ Nonetheless, employment contracts were admittedly only exceptionally.

A qualitative change in the status was brought by the Act of 27 April 1972-Charter of teacher's rights and duties, which formally moved away from the concept of service employment (as part of a service relationship) of university teachers, making them employees within the meaning of labour law. ${ }^{12}$ However, appointment was the basis for the establishment of employment relationship, therefore, the academic staff retained a number of privileges that were related to the previous public-law status resulting from employment in higher education institutions. This situation persisted until 2005, when appointment as the basis for employment of university teachers became an optional institution because the scope of positions covered by this basis was set in the statute of a given university, and it was narrowed only for titular professors in 2011. Ultimately, the Constitution for Science no longer provides for the nomination as a basis for establishing employment relationships, leaving only employment contracts (for a definite and indefinite period) as the appropriate basis for the staffing of posts in higher education institutions.

This is a fundamental change as compared to the previous state of affairs. Appointment was originally a public-law institution used as a basis for establishing service relationships with officers. The service employment regime differed significantly from the standards of contractual employment implemented under private labour law. The officers were employed by the state, they were subject to increased service availability and disciplinary responsibility, and they were also entitled to state pensions after retirement. Stability of employment was also guaranteed for them because the cases of dismissal were strictly limited. Such a legal situation of the officers corresponded to the paradigm of public service based on values such as the loyalty of officers and their absolute devotion to the service, ${ }^{13}$ as well as the

10 The Decree of 28 October 1947 on the organisation of science and higher education, the Act of 15 December 1951 on higher education and on academic staff and the Act of 5 November 1958 on higher education (until 1972).

11 For example, pursuant to Articles 87 and 90 of the Act of 6 November 1958, appointment to the posts of full professor, associate professor, docent (senior lecturer) takes place by nomination, and the service relationship of a person appointed by nomination is established when the nomination letter has been delivered to them.

12 However, legal writers have already questioned the classification of the service relationships of state employees, including university teachers, as public-law constructs, treating the traditional division of the legal system into private and public law as inadequate to the socialist system (M. Jaroszyński, Prawo pracowników naukowych, Ossolineum 1971, p. 118).

13 W. Jaśkiewicz, Studia nad sytuacja prawna pracowników państwowych, Vol. 1, Poznań 1961, p. 105. 
state's custody over persons who are in the state's service. The privileges of service officers were gradually reduced in the times of the Polish People's Republic, and most of them (called state employees) were ultimately covered by labour law at the turn of the 1960s and 1970s (only the officers of the state power ministries maintained the previous service status). This was the case with academic staff, but - as mentioned above - nomination as basis for employment was preserved until 2005. Therefore, it can be said in short that the abolition of appointments leads to the elimination of the separate status of university teachers in comparison to the other employees, thus subjecting them to more flexible standards resulting from the Labour Code (e.g. in relation to issues such as termination of employment), which corresponds to the change in the system of assessments of academic staff and the parameterisation of higher education institutions. However, this is related to the reduction of the protection provided to appointed staff (in particular for stability of employment), which may be of importance in the context of the principle of freedom of education, artistic creation and research, as well as the autonomy of universities (Article 3 of the Law on Higher Education and Science). Of course, the equalisation of the situation of university staff with other employees is not complete, the new law leaves some special rights and obligations adjusted to the specifics of employment of this professional group (e.g. disciplinary responsibility, working time accounting rules or emphasis on the ethical values of employment, which should be served by a prohibition on holding offices by former secret informal collaborators of the security services of the Polish People's Republic). ${ }^{14}$

The modification of the status of academic staff, in particular in connection with the new assessment system indicated above, will probably lead to far-reaching staff changes in higher education in some time. It seems that it will be necessary to verify both currently employed staff (in terms of their academic suitability for a given unit) and the rules of employing new staff (based on reliable competitions). However, it is not sure at all that these changes will be favourable. A condition for a real qualitative change is undoubtedly an increase in expenditure on science, which - in addition to investment in scientific infrastructure and provision of research funds - will lead to gradual approximation of the level of employees' income to

14 It should be pointed out that according to transitional regulations (Article 234(1) and (2) of the regulations implementing the Law on Higher Education and Science), appointed university employees remain employed in the same form and for the same period, and the repealed provisions of the Act on Higher Education regarding appointments will continue to apply to them. In the context of abolishing the appointment in higher education institutions, some systemic doubts may arise from leaving this basis of employment in research institutes and in the Polish Academy of Sciences (Articles 118 and 119 of the bill of the Act - Regulations implementing the Act - Act on Higher Education). 
the standards offered by good foreign universities. If this condition is not met, it will be doubtful to achieve one of the strategic objectives of the reform of higher education, which is to stop labour migration of talented scientists and the resulting contribution to the research potential of foreign universities at the expense of Polish ones. The proposed reform additionally covers the provision of increased funds, also for the salaries of university teachers, but the question arises whether or not the announced increase amounting to PLN 850, though significant as a percentage, will be sufficient.

Concluding from the previous considerations, the introduced reform of higher education and science is systemic. We know what are the goals thereof, we also know what are the means to achieve it. We also know that it will bring far-reaching and profound effects to the functioning of this sphere of social life. We do not know, however, whether they will be positive or negative. Will Polish science finally stand on its feet and be able to compete with world science, or will it descend into chaos? In fact, all scenarios are possible. It is because the reform gives universities opportunities, but it also poses some threats. Is the formula of "one-man rule" of rectors right, especially if it privileges those who were elected in 2016, before we got to know the assumptions of the reform? It seems, however, that if we decide to give so much power to rectors, they should probably be re-verified in terms of the tasks that the new law defines for them. Are we not neglecting the culture-forming and civilisational role of smaller and regional universities by striving to improve the position of Polish science in global rankings?

But on the other hand, can we afford to stand still when the world rushes forward? Is it not necessary to finally break with the "pseudoscience" with its leading manifestation involving concentration on the score? Can we continue to allow ourselves to waste talents? Is it not time to finally restore the ethos of science? Many of the solutions contained in the Constitution for Science may, but need not, contribute to improving the current situation.

In the reform - despite its numerous flaws and deficiencies - there are also positive aspects, perhaps new assessment rules and more flexible forms of employment of academic and teaching staff will lead to enhanced research quality. Nonetheless, we come to the nub of the problem. As Napoleon said, for war we need three things - money, money and more money. This observation is also suited to scientific research. With the current level of funding for science and higher education, it is difficult to expect that the reform will contribute to achieving the intended goals. On the other hand, the system of higher education and science is a bit like a bottomless pit. You can add any amount of money to it, but without any guarantee that it will bring the desired results. 
Therefore, changes are necessary, and with them it is necessary to increase funds for science. Therefore, changes introduced in 2018 in the system of higher education and science are in fact only the first - institutional - stage of the reform, paving the way for further measures. This should be followed by a significant increase in financial outlays and, above all, approximation of the level of salaries of university teachers to the standards in developed countries. Only then will it be possible to expect any effects of the reform. 